\title{
DEVELOPMENT OF SUSTAINABLE RURAL TOURISM
}

\author{
Sandra KANTAR ${ }^{\text {a }}$, Kristina SVRŽNJAK ${ }^{\mathrm{a}}$ \\ a Krizevci College of Agriculture, Milislava Demerca 1, 48260 Križevci, Croatia, skantar@vguk.hr; \\ ksvrznjak@vguk.hr
}

Cite this article: Kantar, S., Svržnjak, K. (2017). Development of Sustainable Rural Tourism. Deturope, 9, $1: 26-34$

\begin{abstract}
This paper presents a sociological view of possibilities for the development of sustainable rural tourism in Koprivnica-Krizevci county, which is located in the north-western part of Croatia. The possibilities for developing rural tourism within the concept of sustainable development have been researched through qualitative empirical research interview method.

Research subjects were the owners of tourist farms, decision makers, experts and other stakeholders in the tourism development. Rural tourism represents an alternative to maritime tourism and is relatively undeveloped but important in terms of development of rural areas and family farms. This paper enables an insight into an integrated sustainability of rural tourism which consists of four dimensions: biologicalecological, economic, socio-cultural and political sustainability. In conclusion, integral sustainability in rural tourism is not achieved in all dimensions. Therefore, rural tourism could be a strategy for sustainable development for rural areas and also could be a tool for product differentiation for area that are at stagnation stage.
\end{abstract}

Keywords: sustainable development, rural tourism, Croatia

\section{INTRODUCTION}

Rural area in Croatia is approximately $91.6 \%$ of its total area. The characteristics of the rural area (which includes Koprivnica-Krizevci county) are: the dominance of agriculture and forestry as branches of industry which employ most local residents; its environment is urban, it is architecturally and aesthetically organized into villages and towns with inadequately developed technical and municipal infrastructure; its socio-cultural milieu practices traditional forms of culture and local social integration is conducted through neighbourhood and family relationships (Lukić, 2012). The rural areas suffer from many negative processes, such as depopulation, deagrarization, demographic aging and masculinisation of the population and lower educational and economic potential of residents in comparison with urban areas.Therefore, a part of the population on farms is developing and diversifying new rural economic activities, such as rural tourism. Rural tourism (Kušen, 2005) is a collective term for different activities and forms of tourism appearing outside of cities and those areas with a developed mass tourism. Rural tourism encompasses all forms of tourism in rural areas, including hunting, fishing, rural, eco-tourism etc. and could be a supplementary but also 
professional business and source of income. The fundamental basis of this paper is that the sustainable development and rural tourism are interdependent and largely conditioned phenomena, as the development of rural tourism represents a significant alternative to mass tourism, manages sustainable resources and incorporates users of this type of tourism in traditional sustainable practices of country life.

The UN Report of the World Commission on Environment and Development Our Common Future, sets the fundamental definition of the sustainable development which defines it as the development which meets the needs of the present generations without compromising the ability of future generations to meet their own needs. The sustainable development is further defined as a process of improving the quality of human life which is carried out within the framework of the so called carrying capacity of sustainable ecosystems. There are three key points in the sustainable development concept: protection of ecosphere, stable economic development and fair distribution of social opportunities. For the purposes of this paper, sociological aspects of sustainable development were considered, according to Lay (2007) who says that the sustainable development is a concept which implies a balanced relationship of biological-ecological, economic, socio-cultural and political dimension. For these four dimensions, special indicators were developed that "cover" the concept of integral sustainability in the rural tourism of Koprivnica-Krizevci county (Figure 1), which were made into questions for participants of the research.

Figure 1 Administrative division KKŽ to towns and municipalities

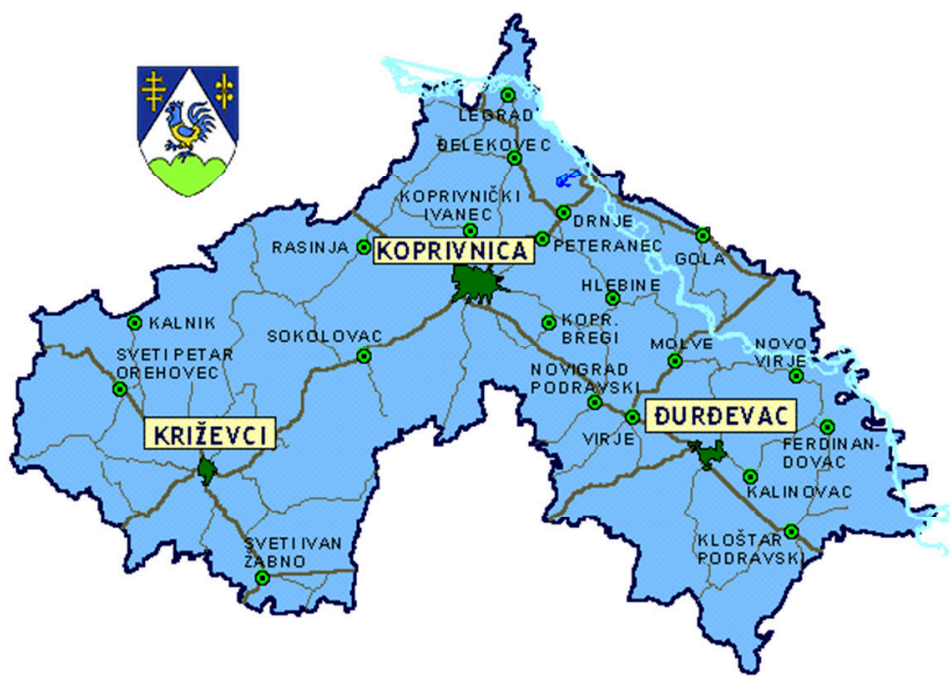

Source: https://kckzz.hr/o-zupaniji/gradovi-i-opcine/

The goal of this paper is to analyse the application of the concept of sustainable development on the existing firms of rural tourism in Koprivnica-Krizevci county, and determine exactly 
how sustainable rural tourism is in the county. The purpose of this paper is to contribute to a better understanding of sustainable rural tourism in Koprivnica-Krizevci county and similar continental areas in Croatia.

\section{OBJECTIVES AND METHODS}

Participants of the research are well aware of the County's large potential in tourism and they participated in the research with enthusiasm by answering the questions in an interview. Thirty participants were interviewed in total, 18 of which are decision makers, and 12 are owners of facilities in rural tourism. What is interesting is that the participants are in different professions, most of which were not closely connected with tourism: they were agronomists, economists, etc. Decision makers in rural tourism (for example municipal prefects, the director of a tourist association etc.) as well as business owners in rural tourism (for example owners of family farms, Bed \& Breakfast proprietors, owners of rural vacation homes etc.) have no formal education in tourism but have a vast knowledge gained though life-long learning and experience in tourism. Currently, these participants are the main stakeholders of the development of rural tourism. Moreover, out of the total number of participants, 19 or $63 \%$ were males and 11 were females. Regarding the age of participants, most of them were between 30 and 45 years of age (43\%). The participants answered about 20 questions about four dimensions of sustainability: biological-ecological, economic, socio-cultural and political sustainability (Lay, 2007) in the form of semi structured interview. As is well known, the interview is an important research method in empirical sociology (Abercombie, et.al., 2008). Generally speaking, a half-structured interview is a research method where the researcher has prepared topics and general questions that need to be addressed in an interview with an interviewee but where a researcher follows the conversation logic and allows an interviewee freedom to answer questions as they see fit, while making sure all relevant topics are covered (Tkalac Vercic et. al. 2014). Considering the fact that there is no qualitative research combined with triangulation method $^{1}$ (Denzin, 2005) on dimensions of rural tourism in Croatia, this represent the first research of the kind ${ }^{2}$ which uses methods of semi-structured interview to determine whether the rural tourism in Koprivnica-Krizevci county is sustainable and in which dimensions.

\footnotetext{
${ }^{1}$ Triangulation method involves the use of a number of sociological method such as observation, comparative method, and semi-structured intervju and was carried out within the research.

${ }^{2}$ This research was conducted for a doctoral thesis: Development of sustainable rural tourism: potentials of Koprivnica-Krizevci county“ (Kantar, S.)
} 


\section{RESULTS}

At the moment, Koprivnica-Krizevci county has seven internationally important attractions (Svržnjak, et.al., 2014), which make the county recognizable and that attract most visitors. They are as follows:

1) River Drava;

2) Regional Park Mura - Drava (protected natural heritage);

3) Holy Trinity Greek Catholic Church and Bishop's Palace (protected cultural historic heritage);

4) Vegeta (universal seasoning);

5) Podravka (headquarters of industrial production of Vegeta);

6) Saint Marko Krizevcanin (Croatian Saint);

7) Ivan Generalic (painter of Hlebine Naive Art School);

However, tourism and rural tourism are currently being developed. Natural (river Drava, Lake Soderica, Kalnik, Lake Cambina, Durdevac Sand Dunes (remnants of a desert) etc.) and cultural potentials (Renaissance Festival in Koprivnica and other local events) should be used for tourism, by developing quality agricultural products through marketing (for example cheese "prgica") which is produced on many farms, developing tourism infrastructure, tourism facilities, increasing accommodation capacity etc. Favourable geographic position, proximity to strong markets and the construction of new roads are just some of the opportunities for using the existing agricultural and food image of the County for the production of ecological food and the development of rural tourism as a supplementary source of income.

Rural tourism could be sustainable tourism or sustainable tourism development that: "... meet the needs of tourists and their hosts protecting and enhancing development opportunities. He wants to achieve resource management in a way that economic, social and aesthetic needs can be achieved in order to maintain the cultural integrity, essential ecological processes, biological diversity and systems of underlying life" (Carić, 2006).

\section{Ecological dimension of sustainability ${ }^{3}$}

The ecological dimension of sustainability in rural tourism is based on putting the emphasis on the importance of the environment and people's attitude towards the environment, promoting ecological values in business, pro-ecological behaviour of tourists, a range of

\footnotetext{
${ }^{3}$ Summing up the results of the research it must be mentioned that all the statements presented in this section are drawn from the interviews.
} 
conducted measures aimed at reducing pollution, waste reduction, water usage reduction and energy saving methods. Participants were asked about how satisfied they were with the state of the environment around some of the rural tourism facilities, and the questions included the following elements: water, air and soil cleanliness, wastewater management system, refuse collection and recycling, noise, state of plants and animals. Also, participants were questioned on whether there was a threat to the environment and what needed to be focused on in order to protect the environment while sustainably using it at the same time. Generally speaking, the participants were mostly satisfied with the state of the environment in which they live and work and did not identify any major pollutants. Considering the fact that the industry (which is usually considered a pollutant) is mostly ruined, more and more people are turning towards agriculture as a way of life than working in commercial production in its classical sense, thus considering the environment clean. The only pollution the participants noticed was the socalled "visual pollution" which refers to the partially constructed villages and unkempt gardens. However, some participants have noticed positive activities in villages which are becoming a sort of a competition in "who can have the most beautiful garden", which in turn increases the total aesthetics of the area. Some villages have containers for sorting waste, which have not been entirely accepted by the local population. This is closely connected to the level of education but also because most household waste is traditionally recycled (composting, recycling).

Satisfaction with the state of the environment is an essential component of sustainable tourism as it ensures that the tourism can survive over a longer period of time because it does not cause the degradation of the environment but it benefits the economic, ecological, social and cultural environment in which it takes place.

\section{Economic dimension of sustainability}

Economic sustainability implies the economic viability of the sustainable way of life and doing business. Therefore, it must be assumed that the rural tourism contributes to the preservation of environmental protection, health, recreation and education of individuals/family, using renewable sources of energy, if those are available, ecological production of food and beverages, authentic cuisine. The participants were asked whether or not the economic profit calculation for farms exists. Considering the fact that the local economy and economic viability are the instruments of survival of life in rural areas, an effective local economy becomes a national interest as well. The need to diversify activities in rural areas, one of which is rural tourism as a potential economic segment, represents one 
of the development tools of the local economy. Unfortunately, according to the answers of the interviewees, economic viability based on traditional and sustainable living practices is not recognized in rural tourism. It is difficult to survive on tourism alone, without a main source of income (e.g. agriculture). Tourism is seen as only supplementary source of income. Consequently, economic/sustainable/traditional living practices in rural tourism facilities, on current conditions, are not economically viable at the moment.

\section{Socio-cultural dimension of sustainability}

Socio-cultural aspect of sustainability implies the authenticity of family relations, compliance with customs and traditions as well as the culture of living in spiritual and material sense. Specifically speaking, this dimension puts into question nurturing of the Podravina and Prigorje regional identity in everyday life and special social occasions. Socio-cultural sustainability which consists of identity, cultural heritage and tradition of this region is visible, for example, in the wealth of cuisine, hospitability, local celebrations, naive art, folklore and religion. Podravina and Prigorje nourish the culture of dining and the cult of working which belong to the regional spirit, life philosophy and the view of the world, which have always been interwoven in this region (Jelušić-Kranželić, 2001). The participants consider the socio-cultural dimension of sustainability to be very important for the development of rural tourism, and consider it represented to a certain extent. The sociocultural identity is nurtured in a wider sense through the regional identity of Podravina, Prigorje and Bilogora, and in a narrow sense through the regional identity, and narrower still as a rural identity of Podravina villages, enogastronomy, national costumes and customs. Most participants emphasized the importance of "being oneself" and the need to keep and foster the socio-cultural dimension. However, there is doubt among the participants that all the stakeholders in rural tourism would unconditionally agree to practice such types of behaviour. An example of insufficient care about rural tourism and the lack of sustainability of the socio-cultural dimension is seen in the abandoned Podravina villages, the decaying state of rural architecture and insufficient promotion of regional identity by young people. In conclusion, additional efforts need to be put into the socio-cultural sustainability, as the awareness of the socio-cultural identity already exists.

\section{Political dimension of sustainability}

Political dimension of sustainability is manifested in the way our society/country selfdefines its cultural identity and destiny as a whole, working and living conditions of people in 
its territory or in other words, self-estimation. It is impossible to organize one's own resources and lives in a sustainable way if the working and living conditions are determined by active participants outside of the society one lives in. The political dimension of sustainability of rural tourism refers to general support in doing business - from the tourist board (county, local), local governments (villages, municipalities...), family, neighbours and so on. The support of the local governments is easily seen through the level of infrastructure in the area with rural tourism facilities and activities which contribute to the quality of life and working of the participants. The participants were not satisfied with the local community support and with municipal infrastructure (sewage system, electricity, water, telephone, Internet) or the tourism infrastructure (tourist sign boards).

When talking about the political dimension of sustainability of rural tourism, its most important component is the support of the close and extended family. Therefore, it is essential to save small family farms, as a considerable number of people live in rural areas and they represent the foundations of life in this region. It can be stated that Croatia is still the country of family food production and, hopefully someday, family farm tourism.

\section{CONCLUSION}

Based on the conducted interviews, it was concluded that there are people in KoprivnicaKrizevci county that have the knowledge, skills, enthusiasm, ideas and vision of the sustainable rural tourism in the County. The possibilities of sustainable development of rural tourism are reaching the highest level in the ecological dimension while results for economic dimension of sustainability are unsatisfactory due to the general reduction in economic activities. The socio-cultural dimension is also not reached at the expected level and the political dimension has been reached partially (only regarding the family support). The results show that the integral sustainability of rural tourism of Koprivnica-Krizevci county has not yet been reached, as it is not based on the equal representation of all dimensions of sustainability, only in ecological and political, with lower results in economic and sociocultural dimensions. Despite recognizing the importance of rural tourism as a possible boost for the development of rural areas, rural tourism in Koprivnica-Krizevci county is in its early stages of development. Due to poorly sustainable global/local conditions of development, it cannot be considered integrally sustainable. Traditional agricultural area, where changes happen slowly or not at all, is significantly less engaged in the development of rural tourism, 
when compared to coastal and island regions. A possible reason lies in the lack of tradition in developing tourism, as opposed to coastal destinations. The other reason probably lies in the relatively passive role of national and/or regional governments, until recently, in the promotion of the development of rural tourism. Apart from that, the social capital is insufficiently developed, and rural population is not ready to accept new models of development based on cooperation and networking. This indicates the fact that the development of tourism is still not seen as the responsibility of the entire community. However, rural tourism is based on sustainable development (Ružić, 2005) and has basic conditions for achieving integral sustainability. These conditions can be found in natural environment, strong family support, development possibilities in primary (agriculture) and tertiary (services) sector of economy and the deeply rooted hospitability. Thus, it is important to strengthen all dimensions of sustainability in rural tourism in order to make it integrally sustainable. Finally, this paper emphasises that rural tourism is the local response of rural regions toward globalization as a relatively new phenomenon reshaping our current world. Rural tourism needs to be in harmony with the multiplicity of uses, needs and demands which characterize rural areas in order for it to be deemed as appropriated and potentially sustainable.

\section{REFERENCES}

Abercombie, N., Hill, S., Turner, B.S. (2008). Rječnik sociologije (Sociology Dictionary). Zagreb: Naklada Jesenski i Turk.

Carić, H. (2006). Održivi turizam u deset koraka: planiranje održivog turizma zasnovanog na baštini i prirodnom naslijeđu: priručnik za upravljanje i razvijanje turističkih regija, destinacija i proizvoda (Sustainable Development in Ten Steps: Planning Sustainable Development Based on Heritage and Natural Wealth: Handbook for Managing and Developing Tourist Regions, Destinations and Products) Zagreb: Institut za turizam, Odraz.

Denzin, N. K., Lincoln, Y.S. (2005). Introduction - The Discipline and Practice of Qualitative Research U: N. K. Denzin, Y. S. Lincoln ed. The Sage Handbook of Qualitative Research, 3rd ed. Available at: http://www.amazon.com/The-SAGEHandbook-Qualitative-Research/dp/0761927573\#reader_0761927573 (Access: 03. 01. 2016)

Jelušić-Kranželić, B. (2001). Podravina i Prigorje: kulturna i prirodna baština (The Regions of Podravina $i$ Prigorje: cultural and natural heritage) Koprivnica: Koprivničkokriževačka županija.

Kušen, E. (2005). Ruralni turizam (Rural Tourism). U: Čorak, S. et.al.: Hrvatski turizam: plavo, bijelo, zeleno (Croatian Tourism: Blue, White and Green): Zagreb: Institut za turizam. 
Lay, V. (2007). Razvoj sposoban za budućnost: prilozi promišljanju održivog razvoja Hrvatske (Development Fit for the Future: Contributions to Reflection on Sustainable Development in Croatia). Zagreb: Institut društvenih znanosti „Ivo Pilar“.

Lukić, A. (2012). Mozaik izvan grada: Tiplogija ruralnih i urbaniziranih naselja Hrvatske. (Mosaic outside the city: Typology of rural and urban settlements in Croatia). Samobor: Meridijani.

Our Common Future (1987). Chapter 2: Towards Sustainable Development. Report of the World Commission on Environment and Development. Available at: http://www.undocuments.net/our-common-future.pdf (Access: 03.01.2016.)

Regionalni operativni program za Koprivničko-križevačku županiju za razdoblje od 2006.2013. (Regional Operational Program for Koprivnica-Križevci County for the period 2006 2013), Koprivnica, 2006. Available at: http://kckzz.hr/user_content/documents/ROP_20062013.pdf (Access: 27.3.2017)

Ružić, P. (2005) Ruralni turizam (Rural tourism). Pula: Institut za poljoprivredu i turizam Poreč.

Svržnjak, K., Kantar, S., Jerčinović, S., Kamenjak, D. (2014). Rural tourism: an introduction to destination management, (prev. Graham McMaster; ed. Renata Husinec), Križevci:College of Agriculture; Denona: Zagreb, 2014.

Tkalac-Verčić, A., Sinčić- Ćorić, D., Pološki-Vokić, N. (2014) Priručnik za metodologiju istraživanja u društvenim djelatnostima: Kako osmisliti, provesti i opisati znanstveno i stručno istraživanje (Manual for research methodology in social activities: How to design, implement and describe the scientific and professional research) Zagreb: MEP. 